\title{
Correction to: Quantification and analysis of Raman spectra of graphene materials
}

\author{
Velram Balaji Mohan ${ }^{1}\left[\right.$ [ Krishnan Jayaraman $^{1} \cdot$ Debes Bhattacharyya $^{1}$
}

Published online: 2 May 2018

(C) Springer International Publishing AG, part of Springer Nature 2018

\section{Correction to: Graphene Technol (2017) 2: 47-62 \\ https://doi.org/10.1007/s41127-017-0012-7}

In the original version of this article Michel Nieuwoudt was listed as second author in the author group. She asked for the removal of her name as she considers her contribution being too minimal to be worth being listed as an author. The remaining authors and the Editor-in-Chief agreed to this request. The corrected author group is given above.

The original article can be found online at https:// doi.org/10.1007/s41127-017-0012-7.

Velram Balaji Mohan

vmoh005@aucklanduni.ac.nz

1 Department of Mechanical Engineering, Centre for Advanced

Composite Materials, The University of Auckland, 314-390

Khyber Pass Road, Newmarket, Auckland 1142, New

Zealand 